\title{
Pure cystic adrenal space-occupying lesion: always rule out cystic pheochromocytoma
}

\author{
Partha Pratim Chakraborty, Shinjan Patra, Sugata Narayan Biswas, \\ Gouranga Santra
}

Department of Medicine, Midnapore Medical College \& Hospital, Midnapore, West Bengal, India

\section{Correspondence to}

Dr Partha Pratim Chakraborty, docparthapc@yahoo.co.in

Accepted 8 August 2016

\section{DESCRIPTION}

A 57-year-old woman was referred for preoperative fitness before planned laparotomy for left adrenal cystic space-occupying lesion (SOL). She had been

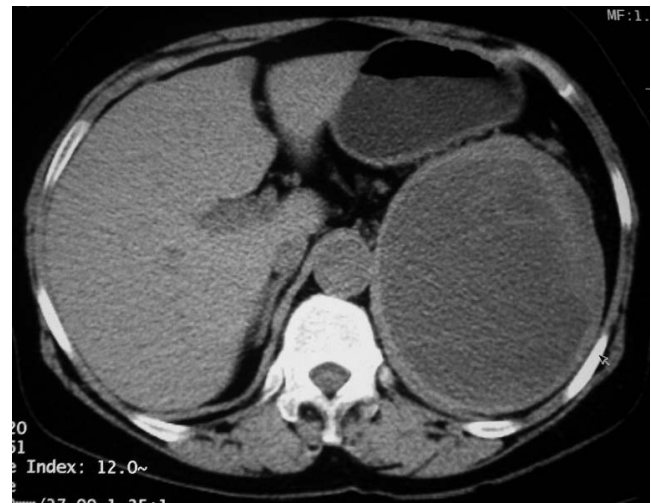

Figure 1 Large purely cystic left adrenal space-occupying lesion in precontrast CT scan. suffering from ill-defined epigastric pain for the preceding 6 months and was found to have a welldefined rounded left suprarenal cystic SOL (11.6 $\mathrm{cm} \times 9.4 \mathrm{~cm} \times 9 \mathrm{~cm}$ ) seen on abdominal ultrasonography. A contrast-enhanced CT scan revealed a purely cystic SOL $(12.1 \mathrm{~cm}(\mathrm{CC}) \times 11.3 \mathrm{~cm}$ $(\mathrm{TR}) \times 10 \mathrm{~cm}(\mathrm{AP}))$ with hyperdense enhancing thin wall in the left suprarenal area and nonvisualisation of the left adrenal gland (figure 1). She was found to have elevated blood pressure $(150 / 100 \mathrm{~mm}$ of $\mathrm{Hg})$ and preoperative evaluation revealed impaired fasting glucose (fasting plasma glucose $110 \mathrm{mg} / \mathrm{dL}$ ) and normal plasma catecholamines (epinephrine $59.1 \mathrm{pg} / \mathrm{mL} \quad$ (reference $<125 \mathrm{pg} / \mathrm{mL}$ ); norepinephrine $303.7 \mathrm{pg} / \mathrm{mL}$ (reference $<600 \mathrm{pg} / \mathrm{mL}$ )). She did not report headache, palpitation, sweating, paroxysmal spells or any of the typical signs and symptoms of glucocorticoid excess. We could not find any previous record of her blood pressure measurements. A relook into the CT scan documented that the precontrast
To cite: Chakraborty PP, Patra S, Biswas SN, et al. BMJ Case Rep Published online: [please include Day Month Year] doi:10.1136/ bcr-2016-216337

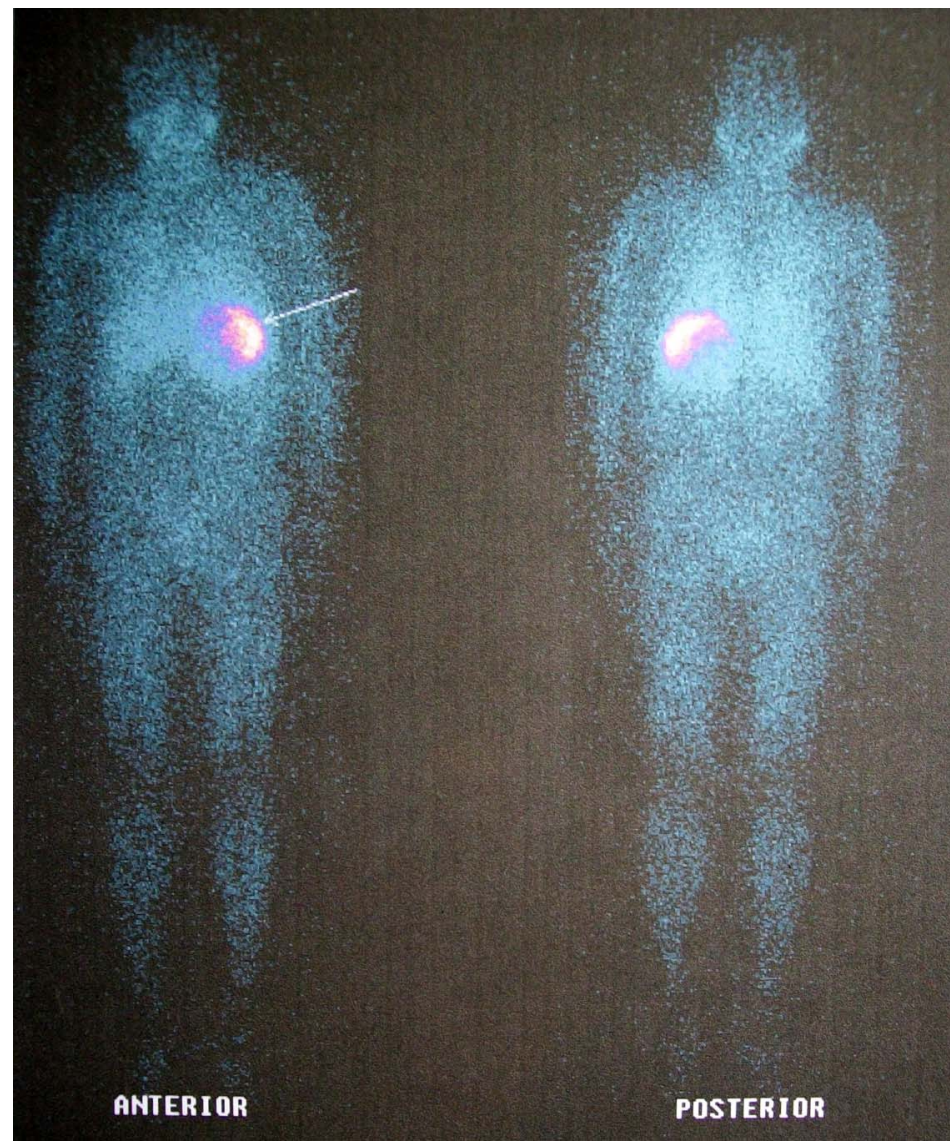

Figure 2 I-131-metaiodobenzylguanidine (MIBG) scan showing solitary MIBG avid lesion in left adrenal. 
Hounsfield unit (HU) of the cystic component was 22 (precontrast $\mathrm{HU}$ of $<10$ is suggestive of lipid-rich benign adenoma). A thorough and systemic work-up for adrenal incidentaloma revealed the following: serum cortisol after $1 \mathrm{mg}$ overnight dexamethasone suppression test: $2.1 \mu \mathrm{g} / \mathrm{dL}$; dehydroepiandrosterone sulfate: $78.9 \mu \mathrm{g} / \mathrm{dL}$ (reference $15-200 \mu \mathrm{g} / \mathrm{dL}$ ). Despite plasma catecholamines being within the reference range, we proceeded for estimation of 24 hours urinary fractionated metanephrines and the values were grossly elevated (metanephrines $5297.6 \mu \mathrm{g} /$ day (reference $<350 \mu \mathrm{g} /$ day); normetanephrines $2598.4 \mu \mathrm{g} /$ day (reference $<600 \mu \mathrm{g} /$ day)). I-131metaiodobenzylguanidine (MIBG) scan documented a single MIBG concentrating mass in the left suprarenal area without any other MIBG avid lesion anywhere in the body (figure 2). A purely cystic solitary left adrenal pheochromocytoma was diagnosed and the patient was put on prazosin and liberal oral salt for 2 weeks followed by propranolol 4 days prior to surgery. The left-sided adrenal mass was removed by laparotomy (figure 3) with normalisation of urinary metanephrines carried out 2 weeks following surgery. The histology of the resected

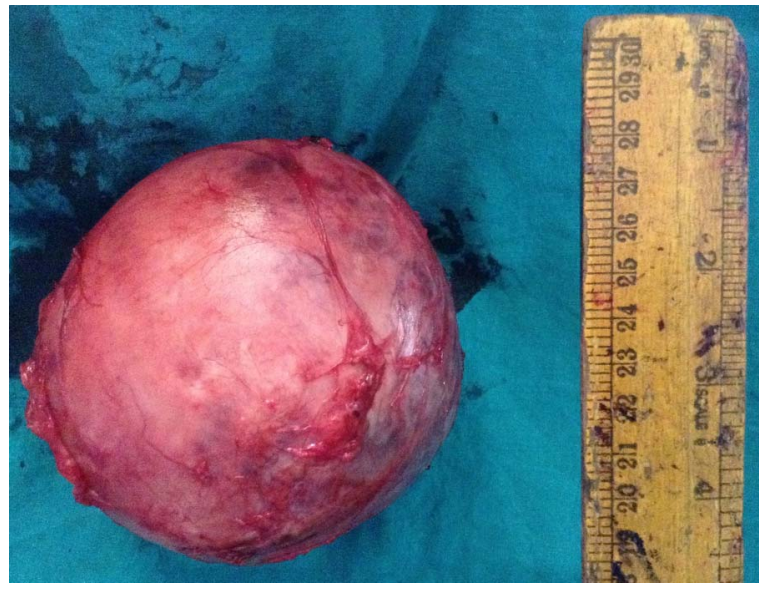

Figure 3 Surgical specimen removed by laparotomy.

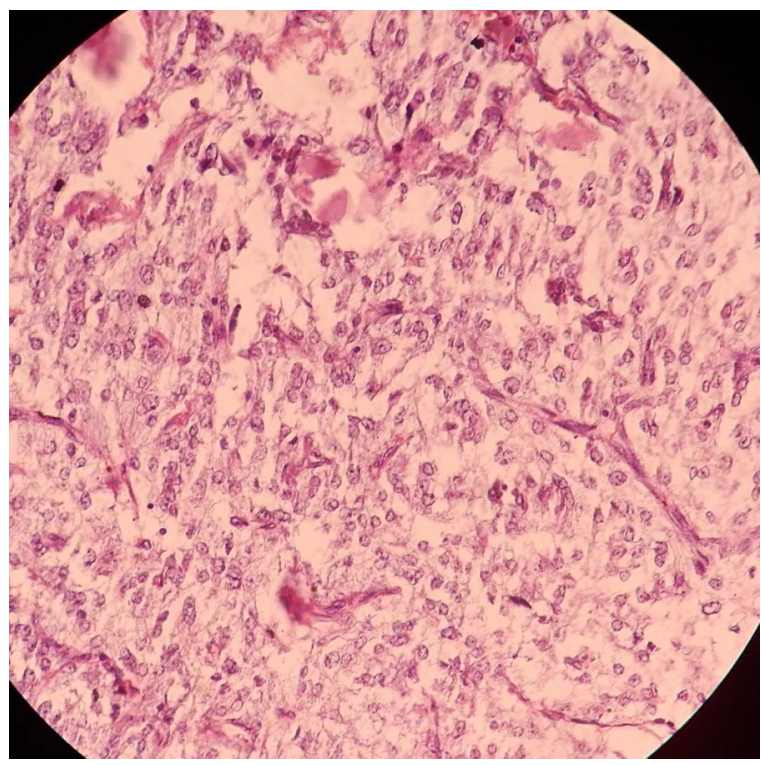

Figure 4 Typical nested to solid pattern of monomorphic polygonal cells having adequate amphophilic cytoplasm (magnification $\times 400$ ).

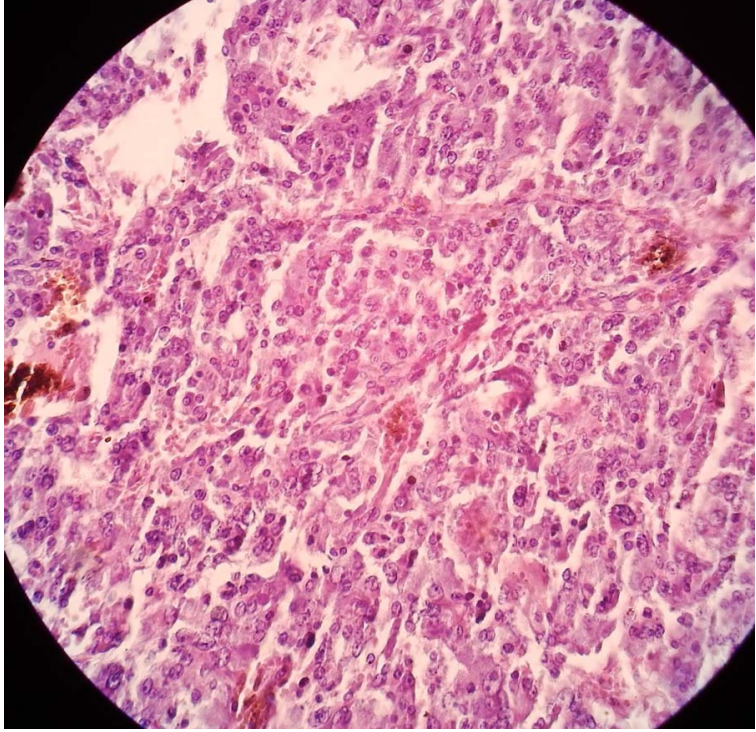

Figure 5 Areas of haemorrhage and pleomorphic cells with giant cell formation. Nested pattern is still maintained. Here cytoplasm is finely granular and eosinophilic. Pleomorphism and giant cell formation are not indicative of malignancy in pheochromocytoma (magnification $\times 400$ ).

mass revealed a typical nested pattern of monomorphic polygonal cells having adequate amphophilic cytoplasm with areas of haemorrhage (figures 4 and 5).

Pure cystic lesions of the adrenal glands having heterogeneity in aetiology and clinical manifestations are uncommon and majority of them represent benign endothelial cysts, epithelial cysts or pseudocysts. Less than $10 \%$ of adrenal incidentalomas have proved to be pheochromocytomas and CT findings consistent with (though not diagnostic of) pheochromocytomas include solid/heterogeneous appearance, increased attenuation on unenhanced CT scan, prominent vascularity of the mass and delayed washout of the contrast. ${ }^{1}$ The exact incidence of pure cystic pheochromocytoma is largely unknown, but about one-fifth of these adrenal medullary tumours may have pure cystic appearance. ${ }^{2}$ Patients with cystic pheochromocytoma are less likely to present with paroxysmal spells/typical symptoms, more commonly present with unusual manifestations like upper abdominal or lumbar pain and have negative biochemical screening tests. Urinary or plasma metanephrines are preferred over urinary/plasma catecholamines as the initial screening test in patients with suspected pheochromocytoma. The sensitivity of metanephrines are much higher than catecholamines as these catecholamine metabolites are produced continuously within these tumours independent of exocytotic catecholamine release, which in many cases is episodic or occurs at very low rates. The pathogenesis of cystic pheochromocytoma has largely been speculated and the inciting event could be the tumour outgrowing its vascular supply. Subsequent intralesional haemorrhage, necrosis and liquefaction within the mass eventually give the tumour a cystic appearance. The lesser tumour burden also makes them less likely to be symptomatic and to have elevated plasma or urinary catecholamines or its metabolites. The cystic component reflects necrosis and has a low attenuation on CT and hyperintense signal on T2-weighted MRI images. However, the characteristic radiological appearance is a relatively thick wall having persistent contrast enhancement which was also present in this patient. 
Learning points

- Purely cystic adrenal lesions with non-specific clinical manifestations may at times be associated with catecholamine excess, which greatly mimic benign lesions and carry detrimental clinical consequences if misdiagnosed.

- All adrenal lesions, even asymptomatic, require a thorough and systemic endocrinological evaluation irrespective of their imaging appearance.

- Considering the poor sensitivity of plasma/urinary catecholamines, screening biochemical testing for suspected pheochromocytoma should include measurements of plasma-free metanephrines or urinary fractionated metanephrines.
Contributors PPC, SP, SNB and GS were involved in diagnosis and management of the patient. PPC, SP and SNB did the literature search. PPC and SP wrote the manuscript. SNB and GS finalised the manuscript. PPC is responsible for the overall content as guarantor.

Competing interests None declared.

Patient consent Obtained.

Provenance and peer review Not commissioned; externally peer reviewed.

\section{REFERENCES}

1 Nieman LK. Approach to the patient with an adrenal incidentaloma. J Clin Endocrinol Metab 2010;95:4106-13.

2 Andreoni C, Krebs RK, Bruna PC, et al. Cystic pheochromocytoma is a distinctive subgroup with special clinical, imaging and histological features that might mislead the diagnosis. BJU Int 2008;101:345-50.

Copyright 2016 BMJ Publishing Group. All rights reserved. For permission to reuse any of this content visit http://group.bmj.com/group/rights-licensing/permissions.

BMJ Case Report Fellows may re-use this article for personal use and teaching without any further permission.

Become a Fellow of BMJ Case Reports today and you can:

- Submit as many cases as you like

- Enjoy fast sympathetic peer review and rapid publication of accepted articles

- Access all the published articles

- Re-use any of the published material for personal use and teaching without further permission

For information on Institutional Fellowships contact consortiasales@bmjgroup.com

Visit casereports.bmj.com for more articles like this and to become a Fellow 